\title{
ACHIEVING AN HONEST RECONCILIATION: ISLAMIC AND INTERNATIONAL HUMANITARIAN LAW
}

\author{
Fajri Matahati Muhammadin* \\ International Law Department, Faculty of Law Universitas Gadjah Mada, Yogyakarta \\ Jalan Sosio Yustisia No. 1, Bulaksumur, Yogyakarta, D.I. Yogyakarta 55281
}

\begin{abstract}
The compatibility between Islamic law and international law has been a long lasting source of both academic discussion and social friction. This includes the Islamic laws on conduct of war (IsHL), especially in context of the Middle East conflicts. This article explores how there are two extreme opinions: 'Islamophobes' and apologists -both of them being dishonest. It will be shown that there are multi-level possibilities of relations between IsHL and International Humanitarian Law including possible incompatibilities, and that an ijma is a good room for reconciliation.
\end{abstract}

Keywords: Islamic law, International Humanitarian Law, jihad.

\section{Intisari}

Kompatibilitas hukum Islam dan hukum internasional telah lama menjadi sumber debat akademis dan friksi social. Termasuk diantaranya adalah hukum Islam terkait pelaksanaan perang, terutama di tengah konflik Timur Tengah seperti sekarang. Artikel ini mengamati dua pendapat ekstrim: 'Islamofobik' dan 'apologist' -keduanya tidak jujur. Akan ditunjukan ada berbagai tingkat kemunginan hubungan antara hukum perang Islam dan Hukum Humaniter Internasional, termasuk diantaranya adalah kemungkinan pertentangan, lalu bagaimana dibutuhkan sebuah ijma untuk menyelesaikan masalah tersebut.

Kata Kunci: Hukum Islam, Hukum Humaniter Internasional, jihad.

\section{Pokok Muatan}

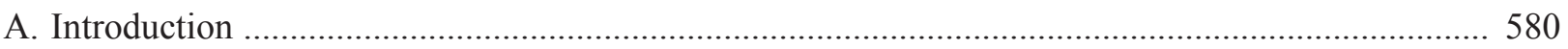

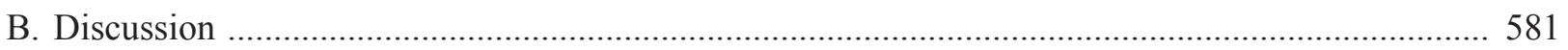

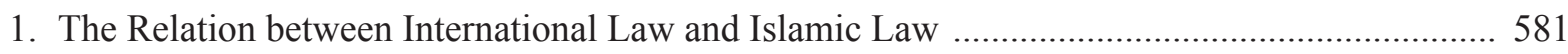

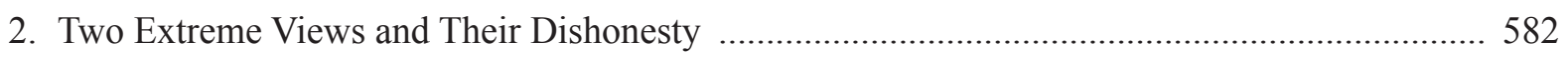

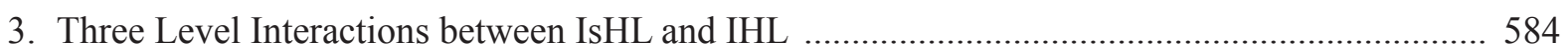

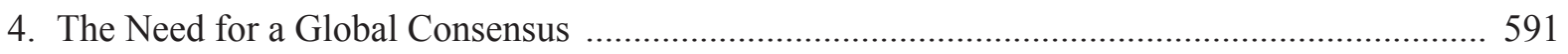

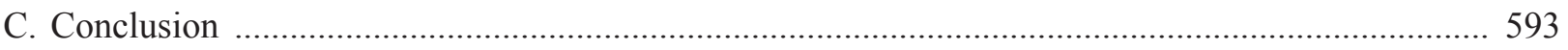

Correspondence address: fajri.matahati@gmail.com 


\section{A. Introduction}

The 2001 attack to the World Trade Center in the USA brought Islam in a spotlight, fueling 'islamophobic' perceptions as well as attacks towards Muslims worldwide. ${ }^{1}$ Much of these objects of 'islamophobic' slanders are seen to be results of misinterpretation of Islamic jurisprudence -both by non-Muslims and a minority of Muslims. ${ }^{2}$ The Muslim world has always fought back to show the world that terrorism is not part of Islam through jurists of various schools of thoughts ${ }^{3}$ and also through their heads of states, ${ }^{4}$ even resulting in some people converting to Islam. ${ }^{5}$

However, when the fight against 'islamophobia' is still going on, tension in the Middle East region brings new 'homework' for Muslims around the world. Streams of persons affiliated to extreme radical groups such as Al-Qaeda are streaming to fight in Iraq, Syria, ${ }^{6}$ and Yemen. ${ }^{7}$ This is not to mention the group "Islamic State" (IS) who are even too extreme for Al-Qaeda ${ }^{8}$ while they control so much territory. ${ }^{9}$ In those conflicts, numerous practices may seem to be in breach of the Geneva Conventions such as: burning ${ }^{10}$ or mass-executing war captives, ${ }^{11}$ and committing slavery. ${ }^{12}$ These groups have issued fatwas or religious rulings to justify such acts, citing primary sources of Islamic law. ${ }^{13}$ Does this mean that Islamic laws of war (or Islamic Humanitarian Law, (hereinafter referred to as IsHL) contradicts International Humanitarian Law (hereinafter referred to as IHL)?

On the other hand, the Islamic states or Islamic-majority states have acceded to the Geneva Conventions 1949 and their additional protocols. ${ }^{14}$ Jurists have authored books and articles on Islamic laws of war, ${ }^{15}$ and most recently over 120 Muslim jurists from around the world signed the Open Letter to Baghdadi against the "Islamic State" group in Iraq and Syria. ${ }^{16}$ This may suggest that IsHL does not contradict IHL.

So which one is correct? How does IsHL really relate to IHL? How to make clarity and reconciliation on this matter? This essay will first explore the general relationship between Islamic law and international law from their sources of law, before in the second place, exploring the two extreme views and their dishonesties. Third, there will be a highlight on three levels of interactions

Halim Rane and Jacqui Ewart. "The Framing of Islam and Muslims in the Tenth Anniversary Coverage of 9/11: Implications for Reconciliation and Moving On", Journal of Muslim Minority Affairs, Vol. 32, No. 3, September 2012, pp. 310-322, at pp. $312-313$.

Wael B. Hallaq, 2009, An Introduction to Islamic Law, Cambridge University Press, New York, p. 1.

Salafi movement: Muhammad Nasir ud-Deen al-Bani, "Warning Against the Fitnah of Takfeer" http://abdurrahman.org/faith/ warningTakfirAlbani.html, accessed on 16 April 2015. Sufi movement: Muhammad Tahir-ul-Qadri, "Fatwa on Terrorism and Suicide Bombing", http://www.quranandwar.com/FATWA\%20on\%20Terrorism\%20and\%20Suicide\%20Bombings.pd, accessed on 16 April 2015. Ash'ari school: Muhammad Afifi Al-Akiti, "Defending the Transgressed by Censuring the Reckless Against the Killing of Civilians", http:// www.warda.info/fatwa.pdf, accessed on 16 April 2015.

See the Cairo Declaration of Human Rights in Islam (1990), hereinafter: Cairo Declaration.

Huffington Post, "Conversion to Islam One Result of Post-9/11 Curiosity", http://www.huffingtonpost.com/2011/08/24/post-911-islamconverts_n_935572.html, accessed on 16 April 2015.

6 The Independent, "Syria Conflict: Idlib City Falls to Jabhat al-Nusra as President Assads forces Flee, Jihadists Claim", http://www.independent. co.uk/news/world/middle-east/syria-conflict-idlib-city-falls-to-jabhat-alnusra-as-president-assads-forces-flee-jihadists-claim-10141020. html, accessed on 16 April 2015.

BBC, "Yemen Crisis: Who is Fighting Who?", http://www.bbc.com/news/world-middle-east-29319423, accessed 16 April 2015.

Abu Baseer Al-Tartousi, "A Declaration Regarding the Fighting Between the ISIS and the Mujahideen of Al-Sham", http://www.abubaseer. bizland.com/hadath/Read/hadath\%20101.pdf, accessed on 16 April 2015.

$9 \quad$ New York Times, "Multiple Fronts in the Fight Against ISIS", http://www.nytimes.com/interactive/2014/06/12/world/middleeast/the-iraq-isisconflict-in-maps-photos-and-video.html? $r=0$, accessed on 16 April 2015.

10 New York Post, "ISIS Burns Pilot Alive, Jordan Responds with Terrorist Executions" http://nypost.com/2015/02/03/isis-video-appears-toshow-jordanian-pilot-being-burned-alivel, accessed 16 on April 2015.

11 McClatchy DC, “Al-Qaida's ISIS Takes 2 Syrian Cities, Executes Scores of Rivals", http://www.mcclatchydc.com/2014/01/13/214335/alqaidas-isis-takes-2-syrian.html, accessed on 16 April 2015.

12 News Week, "ISIS Publish Pamphlet On How to Treat Female Slaves", http://www.newsweek.com/isis-release-questions-and-answerspamphlet-how-treat-female-slaves-290511, accessed on 16 April 2015.

13 See $i b i d$, and find a screenshot of the official fatwa at El Watan News, "Da'esh Issues Fatwa to burn Al Kasasbeh", http://www.elwatannews. com/news/details/654891, accessed on 16 April 2015.

14 See the ICRC official Website, https://www.icrc.org/applic/ihl/ihl.nsf/vwTreaties 1949.xsp, accessed on 16 April 2015.

15 See, for example, Ghazi bin Muhammad et al. (Eds.), 2013. War and Peace in Islam: The Uses and Abuses of Jihad, The Royal Islamic Strategic Studies Centre and the Islamic Texts Society, Cambridge.

16 World Islamic Scholars, "Open Letter for Baghdadi”, http://www.lettertobaghdadi.com/, accessed on 16 April 2015. 
between IsHL and IHL: consistencies, possible positive differences, and possible conflicts. Finally, in the fourth place, this essay will explore the importance of a global consensus both from the perspective of IsHL and IHL.

\section{B. Discussion}

\section{The Relation between International Law and Islamic Law}

A very simple reading of Article 38(1) of the Statute of the International Court of Justice (ICJ Statute) would not show any sources of Islamic Law. Also, one would not simply find international law in a simple reading of any texts of fiqh (Islamic jurisprudence). However, a deeper analysis of both bodies of law will show that there may be room for the two bodies of law to recognize each other.

\section{a. Islamic Law from the Perspective of International Law}

Article 38(1)(c) of the ICJ Statute mentions that one of the sources of international law is "the general principles of law recognized by civilized nation", which may include Islamic law. ${ }^{17}$ This is because Islamic law is practiced (wholly or partially) by numerous states. ${ }^{18}$ Further, while applying and practicing Islamic law, a vast majority these states are also parties of major international law instruments including but not limited to the United Nations Charter,
International Covenant for Civil and Political Rights (ICCPR), the Geneva Conventions 1949, the Convention on the Elimination of Discrimination Against Women (CEDAW), and others. ${ }^{19}$

A very liberal (but not too persuasive) reading of Article 31 and 32 of the Vienna Convention on the Law of Treaties 1969 would show how the practice of the Islamic states can possibly be an alternate way to interpret certain parts of international law. Failing that, the practice of these Islamic states can probably be seen as a persistent objector, excluding them to the general rule. ${ }^{20}$ Or, might it be a 'regional' customary law? ${ }^{21}$

However, the debates will continue. ${ }^{22}$ This essay will focus and explores one of the hearts of the debates, which is the law of the conduct of armed conflict.

\section{b. International Law from the Perspective of Islamic Law}

It may seem like a very common attribution to radical Muslims that they denounce the 'laws of the kafir (nonMuslims)'. The attribution of such a statement to 'radical Muslims' is not entirely correct because some verses of the Qur'an mention clearly that "[...] those who do not judge by what Allah has revealed [...]" are either “..kaafiruun", ${ }^{23}$ "dzaalimuun" (oppressors) ${ }^{24}$ or "..faasiqeen" (disobedient). ${ }^{25}$ Being verses of the Qur'an, it should be primary law for the Muslims, as per Surah An Nisa, 4: 59.

\footnotetext{
17 James Cockayne, "Islam and International Law: from a Clash to a Conversation between Civilizations", International Review of the Red Cross, Vol. 84, No. 847, September 2002, pp. 597 -626, p. 623.

18 Including but not limited to: Palestine, Saudi Arabia, the United Arab Emirates, Qatar, Oman, Pakistan, Bahrain, Yemen, Sudan, Brunei Darussalam, Malaysia, etc, See the constitutions of the mentioned states, and also the Arab Charter of Human Rights.

19 See the following: UN Treaty Collection (UNTC), for CEDAW, "Treaties", https://treaties.un.org/Pages/ViewDetails. aspx?src=TREATY\&mtdsg_no=IV-8\&chapter=4\&lang=en, accessed 16 April 2015, United Nations Official Website, for the UN Charter, http://www.un.org/en/members/, accessed 16 April 2015 ICRC Official Website, for the Geneva Conventions 1949, https://www.icrc.org/ applic/ihl/ihl.nsf/vwTreaties 1949.xsp, accessed 16 April 2015.

20 Malcom Shaw, 2008, International Law (Sixth Edition), Cambridge University Press, New York, p. 91.

21 As observed in the Eritrea v. Yemen Arbitration, PCA, Award of 1996, para 92, and also Asylum Case (Columbia v. Peru), Merits Judgment, ICJ Reports 1950, p. 266, at pp.276-278, and for further discussion see Malcom Shaw, Ibid., pp. 92-93..

22 See the UNTC pages, for example, on CEDAW and the ICCPR. A number of Islamic states have made declarations or reservations based on Islamic law, and some other states have mentioned their objection to it.

Surah Al Maidah, 5: 44.

Surah Al Maidah, 5: 45.

Surah Al Maidah, 5: 47.
} 
However, it is incorrect to just simply cut up certain verses from the Qur'an and see it in isolation. Interpreting the Qur'an should consider the entirety of the Qur'an, the Sunnah, opinions of the 'Pious Predecessors', and rules of the Arabic language. ${ }^{26}$ Even then, we do not always find direct rulings. So the most qualified jurists make fatwas by deducing rulings from the aforementioned primary sources, through ijtihaad (reasoning), considering a number of factors inter alia: qiyaas (analogy), istihsan (juristic preference), maslaha (public interest or benefit) in light of the maqqasid shari'ah (purpose of the law), and other things. ${ }^{27}$

The aforementioned quotes from Surah Al-Maidah refers to blatant rejection towards Islamic laws and oppressing others of their rights. ${ }^{28}$ Entering into agreements with the kafir, however, is permissible. Prophet Muhammad has done so at the Treaty of Medina, ${ }^{29}$ the Hudaybiyah Treaty, ${ }^{30}$ and others. Jurists further explain treaties with the kafir are made when the content of such agreement will benefit the Muslims, ${ }^{31}$ and fulfilling them is compulsory. ${ }^{32}$ Therefore, there is room for Islamic law to recognize international law.

Customary international law can arguably also be a source by two paths: customary laws rising from or codified in international agreements to which Islamic states are party to ${ }^{33}$ as well as $\operatorname{urf}$ (customs) which may be a consideration in making ijtihaad. ${ }^{34}$

\section{Two Extreme Views and Their Dishonesty}

\section{a. "A Good Kafir is a Dead Kafir"}

It has to be admitted that there are parts of Islamic law that may be seen as being in friction with parts of international human rights law. ${ }^{35}$ However, the view that this subsection is about to discuss argues that Islamic law likes to kill all non-Muslims. These views are that of the 'islamophobes'. An example to this group would be the Britain First group, stating inter alia the famous traveler Marco Polo and a professor named M. Saibeski who allegedly said "The militant Muslim is the person who beheads the infidel, while the moderate Muslim holds the feet of the victim." ${ }^{36}$ These views are extremely dishonest not only because these quotes are false. ${ }^{37}$ There are clear and vast evidences of Muslim believing exactly to the contrary. We have seen the overwhelming condemnation towards violent ideology of extremist groups, ${ }^{38}$ therefore such a view does not represent the views of Muslims in the world.

26 Ahmad Von Denffer, 2014, Ulum al Quran: An Introduction to the Sciences of the Quran, The Islamic Foundation, Leicestershire, pp.103-104, note that the Pious Predecessors means the Companions of Prophet Muhammad, one generation after, and one generation after that.

27 Note 2, Hallaq, pp. 22-25.

28 Ismail ibn Kathir (d.1373). Tafsir al-Qur'an al-Adzeem, translated version: ibn Kathir, 2000, Tafsir ibn Kathir (Trans.by Safiur-Rahman AlMubarakpuri), Darussalaam Publishing, Riyaadh, in Vol. 3, pp. 187-189.

29 M. Adil Salahi, 1995, Muhammad: Man and Prophet, Elements Books, Dorset, pp. 222-223.

30 Note that this agreement was almost entirely drafted by the kafir. See: Ibn Hisham (d.833). Sirah Nabawiyah, translated version: Ibn Hisyam, 2006, Sirah Nabawiyah (translated to Bahasa Indonesia by Fadhli Bahri), Darul Falah, Bekasi, p. 203.

31 Salih al-Fawzan bin Fawzan, nn, Kitab Durus Fi Syarhi Nawaqidhil Islam, Maktabah Ar-Rushd, Saudi Arabia, pp. $170-172$.

32 Surah Al Maidah, 5:1, Surah At-Tawbah, 9:4, Surah An-Nahl, 16: 91, and so much more.

33 For example, the Geneva Conventions 1949 which are also customary international law. For extensive evidence of the customary law status of provisions of IHL, see: Louis Doswald-Beck and Jean-Marie Haenckarts, 2005, ICRC Customary International Humanitarian Law, Vol II: Practices, Cambridge University Press, Cambridge.

34 Mawil Izzi Dien, 2004, Islamic Law: From Historical Foundations to Contemporary Practice, University of Notre Dame Press, Notre Dame, pp. 60-61.

35 For example on possible conflicts between Islamic laws related to gender equality and particularly in inheritance law, which is subject to debate see generally: Fajri Matahati Muhammadin, "The GPH-M.I.L.F. Agreement: Human Rights Provisions and Possible Overlaps", Jurnal Cita Hukum, Vol. I, No. 1, July 2014.

36 See: 'islamophobia' Watch, “Another Fake Anti-Islam Quote from the Far Right”, http://www. 'islamophobia'watch.co.uk/another-fake-antiislam-quote-from-the-far-right/, accessed 16 April 2015.

37 Marco Polo never actually said the aforementioned quote and Professor M. Saibeski may seem to be a fictional person. See: Ibid .

38 The Organization of the Islamic Conference (OIC) even adopted a Convention on Combating International Terrorism in 1999. 


\section{b. The Other Extreme: Muslim Apologists}

On the other pole are the apologists. They mean well by denouncing the accusations towards the Muslims but in dishonest ways. A big example would be the famous statement 'Islam has nothing to do with terrorism' ${ }^{39}$ However, some Islamic jurists are that extreme. Sayyid Qutb, for example, proclaimed that even the 'so-called Muslims of today' are all apostates, so they and the kafirs and must be attacked. ${ }^{40}$ These ideas influenced Abu Mus'ab al-Zarqawi (exleader of Al-Qaeda in Iraq) to indiscriminately attack Shi'ite civilians in Iraq. ${ }^{41}$

One cannot simply refute them with a mere few citations from the Qur'an, ${ }^{42}$ and the works of Qutb actually cite primary sources of Islamic law.

A more contemporary issue would be IS. Many have argued vehemently how there is nothing Islamic about the IS. ${ }^{43}$ However it is apparent that IS justifies their acts with fatwas citing primary sources of Islamic laws as well. ${ }^{44}$ The IS fatwa justifying the burning of captives has been refuted widely, inter alia by the Fatwa Committee of Egypt, ${ }^{45}$ pointing out that IS arguments were either not authentic or improperly understood. ${ }^{46}$ Not suggesting that these views are legitimate, but the statement 'Islam has nothing to do with terrorism' does not address the problem correctly.

A more obvious example of Islam's apologists would be the Open Letter to Baghdadi. Some of its contents are blatantly dishonest. The first case is the matter of slavery. Para 12 of the letter says "No jurist of Islam disputes that one of Islam's aims is to abolish slavery.", while there are actually legitimate jurists saying it is within the discretion of the Muslim leader to reenact slavery. ${ }^{47}$

Further, at the ending, the letter cites an alleged quote by the fourth Caliph Ali ibn Abi Thalib which possibly predicts the coming of IS as a deviant group. ${ }^{48}$ However, this is a fabricated statement. ${ }^{49}$ This does not fare well with the claim that IS has 'nothing to do with Islam', while over 120 Muslim jurists signed this letter.

39 Among those who state this, the UN Security Council mentioned "[...] terrorism [...] cannot and should not be associated with any religion [...]" in Resolution No. 2170 (2014), preamble para. 6.

40 Sayyid Qutb (d.1964). Ma'alim fi al-Thareeq, translated version: Sayyid Qutb, 2006, Milestones, Islamic Book Service Publisher, New Delhi, pp. 66-67 and the entire Chapter 4.

41 This man's ideology is even too extreme and therefore denounced even by the central Al-Qaeda command and senior jihadist jurist (alZarqawi's mentor) Abu Muhammad al-Maqdisi. See: George Michael, “The Legend and Legacy of Abu Musab al-Zarqawi”, Defence Studies, Vol. 7, No. 3, September 2007, pp. 338-357, especially pp. 346-347.

42 One of the favorite verses would be Surah Al-Maidah, 5:32 "[...] whoever kills a soul unless for a soul or for corruption [done] in the land - it is as if he had slain mankind entirely $[\ldots]$ ".

43 An example to this is the article of Mehdi Hasan, claiming that there is totally nothing religious in the views and motives of the IS. See: Mehdi Hasan, "How Islamic is Islamic State?", http://www.newstatesman.com/world-affairs/2015/03/mehdi-hasan-how-islamic-islamicstate, accessed 16 April 2015.

44 News Week, "ISIS Publish Pamphlet On How to Treat Female Slaves", http://www.newsweek.com/isis-release-questions-and-answerspamphlet-how-treat-female-slaves-290511, accessed on 16 April 2015.

45 Dar al-Ifta al-Missriyyah, "Egypt's Dar al-Iftaa Vehemently Condemns the Heinous Murder of the Jordanian Pilot by the Bloodthirsty QSIS, http://eng.dar-alifta.org/foreign/ViewArticle.aspx?ID=660\&CategoryID=1, accessed 16 April 2015.

46 Mawil Izzi Dien, Op.cit., pp.38-39. See also Denffer, Op.cit., pp. 7-8.

47 Fatwa Committee of the Kingdom of Saudi Arabia, Fatwa No. 1977, Part No. 16 Page 569-572, English version of Fatwa al-Lajnah adDa'imah, http://www.alifta.com/default.aspx?languagename=en\#1, accessed 16 April 2015. See also Note 15, Ghazi et al, the entire book does not even mention the issue of slavery at all.

48 The Open Letter to Baghdadi cites this quote from a book called Kitab al-Fitan, by Nu'aym ibn Hammad:

When you see the black flags, remain where you are and do not move your hands or your feet. Thereafter there shall appear a feeble insignificant folk. Their hearts will be like fragments of iron. They will have the state. They will fulfil neither covenant nor agreement. They will call to the truth, but they will not be people of the truth. Their names will be parental attributions, and their aliases will be derived from towns. Their hair will be free-flowing like that of women. This situation will remain until they differ among themselves. Thereafter, God will bring forth the Truth through whomever He wills.

49 For example, Imam ad-Dhahabi, a prominent scholar of hadith, has noted that works of Nu'aym ibn Hammad especially Kitab al-Fitan contains fabricated and dubious hadith and may not be used as legal evidence See: Imam ad-Dhahabi (d.1348). Siyaar A'lam An Nubala', modern re-publication: Imam ad-Dhahabi, Siyaar A'lam An Nubala', Dar al-Hadith, Cairo, Vol. 10 para. 609. Very ironic, since 'lack of authentic evidence' was also the basis of refuting IS in the captive burning fatwa. 


\section{Three Level Interactions between IsHL and IHL}

After it has been shown how there are two extremes and both have been seen to be incorrect, one would yearn for a more honest explanation. There are three levels from which one can see how IsHL and IHL relate to each other:

\section{a. Interaction I: Possible Compatibili- ties between IsHL and IHL}

As many jurists -including the apologists - may correctly identify, there is a general compatibility if one analyzes the general principles of IHL and IsHL.

\section{1) The Principle of Humanity}

IHL's basic ontological foundation is the principle of humanity, which is why the laws of conduct of war is called international 'humanitarian' law -to humanize war to the furthest extent possible. ${ }^{50}$ The ICRC explains that the humanity principle means:

[...] prevent and alleviate human suffering... protect life and health and to ensure respect for the human being [...] mutual understanding, friendship, cooperation and lasting peace amongst all peoples. ${ }^{51}$

As a matter of ontology, Islam has a different basis. ${ }^{52}$ However, in general, the same items above are believed also in Islam. Islam inclines to promote similar values. ${ }^{53}$ Further, Islamic law considers the maqqasid shari'ah, (purpose of law) i.e. to protect: life, religion, wealth, mind, and lineage. ${ }^{54}$ Therefore, as a matter of generality, there may seem to be compatibility between IsHL and IHL.

\section{2) The Principle of Distinction and Necessity}

The idea of this principle is to distinguish persons with combatant status and non-combatants. ${ }^{55}$ Civilians, normally non-combatants, may lose their protection status if they participate in the hostilities ${ }^{56}$ while combatants may become noncombatants when they surrender. ${ }^{57}$ The principle of necessity dictates how an object may not be attacked unless it is a military objective which may offer some military advantage. ${ }^{58}$ Therefore, the rule may seem to be that the distinction is based on the extent of their participation in combat.

IsHL also finds similar rules. The Qur'an in Surah Al Baqarah, 2: 190-193 says:

Fight in the way of Allah those who fight you but do not transgress. Indeed. Allah does not like transgressors $[\ldots]$. But if they fight you, then kill them [...] But if they cease, then there is to be no aggression except against the oppressors $[\ldots]$.

Further, Prophet Muhammad commanded "[...] he must not slay

\footnotetext{
See generally: Eva Wartel, "Humanitarians and their Moral Stance in War: the Underling Values", International Review of the Red Cross, Vol. 876, December 2009, pp. 779-802. 
infants, serfs, or woman", ${ }^{59}$ and the first Caliph Abu Bakr instructed his general:

Do not kill women or children or an aged, infirm person. Do not cut down fruit-bearing trees. Do not destroy an inhabited place. Do not slaughter sheep or camels except for food $[\ldots . . .]^{60}$

At another time there are cases where Prophet Muhammad destroyed and burnt trees, but that was because the enemy utilized them as a fort. ${ }^{61}$ The conclusion is similar to that of IHL: combatants are distinguished from non-combatants from their participation in combat.

\section{3) The Principle of Propor- tionality and the Prohibition to Cause Unnecessary Suffering}

This principle prohibits launching an attack which may be expected to cause incidental loss to non-combatants excessive to the military advantage. ${ }^{62}$ Modern warfare technology makes it almost impossible to entirely avoid incidental losses, thus the standard is to avoid these incidental losses by precautionary measures. ${ }^{63}$ In other words, incidental losses can be tolerated. ${ }^{64}$

In the case of prohibition to cause unnecessary suffering, IHL through Article 35(2) of AP I has prohibited the use of weapons which may cause superfluous injury and unnecessary suffering. Torture may be put under this category as well, and is illegal both under IHL and general international law. ${ }^{65}$

With regards to proportionality, IsHL has no explicit rule, except quite implicitly from the previously mentioned command of Prophet Muhammad, ${ }^{66}$ and the Qur'an saying “[...] but do not transgress." More hints on can be found from two traditions of Prophet Muhammad which may, at a glance, seem contradictive.

The first was a story of a night raid conducted by the Muslim army and some women and children were killed, and upon the news Prophet Muhammad said: "they were among them"67 -suggesting that such an act is tolerated. While, on the other hand, we have seen the sayings of Prophet Muhammad and Abu Bakr prohibiting the killing of women and children in war. How do we put these seemingly contradictory sayings into perspective?

Even among the most radical jihad handbooks, ${ }^{68}$ it is mentioned that there are two different opinions: ${ }^{69}$ that the prohibition to kill women and

60 Malik ibn Anas (d.795). al-Muwatta, English translation: Imam Malik, 1992, Al-Muwatta Malik (English Translation by Aisha Abdurrahman Bewley), Madinah Press, Granada, Chapter 21, para. 10.

61 Ibn Rushd (d.1197). Bidayat wal-Mujtahid, English translation: ibn Rushd, 2000, The Distingished Jurist's Primer (English Translation by Imran Ahsan Khan Nyazee), Garnet Publishing, Reading, Vol. I, p. 461.

62 Louis Doswald-Beck and Jean-Marie Haenckarts, 2005, ICRC Customary International Humanitarian Law, Vol I: Rules, Cambridge University Press, Cambridge, Rule 12.

63 Prosecutor v. Kupreskic et al., Trial Chamber Judgment, the International Criminal Tribunal for the former Yugoslavia, (2000), paras.524-525. Ibid.

Article 75(2)(a)(ii) of AP I, see also the Convention Against Torture.

Ismail ibn Rushd (d.1197), Op.cit.

67 Imam Muslim, (d.875), Al-Musnadu Al-Sahihu bi Naklil Adli, English translation: Imam Muslim, 1972, Sahih Muslim (English translation by Abdul Hamid Siddiqi), Ashraf Press, Lahore, Vol. 4, para. 1745b.

68 This book is one of the basic handbooks used in Al Qaeda training camps. Abdul Qodir bin Abdul Aziz (1950-today), "Ma'aalim Asasiyah Fil Jihad, Panduan Fikih Jihad Fii Sabilillah, (trans. by Abdul Qodir bin Abdul Aziz)", http://kopet.pun.bz/files/syaikh-abdul-qodir-abdul.pdf, accessed on 16 April 2015

69 Ibid, pp. 139-143. 
children has abrogated the tolerance towards $i t,^{70}$ and that both sayings are not contradictory, rather they only indicate that women and children should not be killed as a general rule, but if it occurs due to accident then it may be tolerated..$^{71}$

The second tradition is the command of $\mathrm{Abu}$ Bakr prohibiting inter alia the cutting of trees on one hand, while on the other hand, we see the Prophet Muhammad commanding the cutting and burning trees when militarily necessary. How do these rules imply a rule of proportionality and requirement of precaution?

Islam teaches the concept of istiqamah (steadfastness), ${ }^{72}$ meaning to fulfill the law in the best way possible. ${ }^{73}$ Consequently, it is an inherent obligation in every rule in Islamic jurisprudence that a Muslim should endeavor to obey such rules and avoid disobeying them. One may also consider a maxim in Islamic jurisprudence: "the removal of harm takes precedence over achieving maslaha" ${ }^{74}$ Therefore, although it may be not so explicit, IsHL does require proportionality in conducting warfare.

With regards to torture or causing unnecessary suffering, the
Sunnah shows a very clear prohibition of torture and causing suffering towards both humans and even animals, ${ }^{75}$ even for the purpose of obtaining information. ${ }^{76}$

\section{b. Interaction II: IsHL Possibly Having Higher Standards of Protection}

Little is it known that there are at least two rules where IsHL may seem to offer higher standards of protection towards the protected persons rather than that of IHL.

1) Humane Treatment Towards War Captives

IHL has a set of provisions to protect war captives. Article 13-14 of the $3^{\text {rd }}$ Geneva Convention 1949 demands a detaining power to treat captives humanely and with respect. Further, there are more elaborate rules prescribing sufficient food and clothing, ${ }^{77}$ hygienic conditions of quarters, ${ }^{78}$ which should be as favorable as the detaining power's soldiers living in the same area. ${ }^{79}$

IsHL, as a compulsory rule, prescribes similar standards. The humane treatment towards war captives are strictly commanded by Prophet Muhammad in the Sunnah. ${ }^{80}$ Captives are not allowed to suffer the heat of the sun, and their food, clothing, and healthcare, were under

\footnotetext{
This view is supported by a commentary of the hadith by Az-Zuhri, a scholar among the Pious Predecessors, see Note 61, Abu Dawud, Para. 2627, see also Note 63, ibn Rushd, p.461, about the command of Abu Bakr possibly indicating an abrogation of past statements of Prophet Muhammad.

71 This type of view to reconcile sayings of Prophet Muhammad instead of abrogating them is the method of Imam Shafi'i as seen in his Risala. See also Majid Khadduri (Ed), 1987, Al-Shafis Risala: Treatise on the Foundations of Islamic Jurisprudence, The Islamic Texts Society, Cambridge, p. 37.

72 Surah Fussilat, 41: 30, Surah Hud, 11: 112, etc.

Musthafa al-Bugha et al., 2006, Syarah Riyadus Shalihin, Darul Uswah, Yogyakarta, pp. 181-183.

Legal maxims are used as guides to deduce rulings also. See: Abu Umar Faruq Ahmad et al., "Shari'ah Maxims and Their Implication on Modern Financial Transactions", Journal of Islamic Economics, Banking and Finance, Vol. 6, No. 3, July-September 2010 , pp. 76-104.

Abu Dawud, Op.cit., para. 5248, and para. 6327.

Ibid., para. 4369.

Articles 26-28 of the $3^{\text {rd }}$ Geneva Convention 1949.

Article 29 of the $3^{\text {rd }}$ Geneva Convention 1949.

Article 25 of the $3^{\text {rd }}$ Geneva Convention 1949.

Ismail ibn Kathir, Op.cit., p. 289.
} 
the responsibility of the detaining powers. ${ }^{81}$ To this point, it may seem that there is a simple compatibility between IsHL and IHL. However, Islamic jurisprudence does not only recognize halaal (lawful) and haram (prohibited), but also mustahab or encouraged acts. $^{82}$

What is wajib has been explained earlier: mere humane treatment. However, there is an act which is mustahab with regards to the treatment of these captives: treat the captives well and even better than your own soldiers.

The Qur'an in Surah Al Insan, 76: $6-8$ puts feeding a captive in the same line as feeding orphan and indigent, with an great abundance of virtues in doing so ${ }^{83}$ So the Companions of Prophet Muhammad then gave preference in treating the captives than themselves, such as providing better meals than what they themselves ate. ${ }^{84}$

It is well understood that such a treatment is not always feasible, as well as how it is not compulsory. However, it must be understood how Islamic law integrates jurisprudence, virtue, and religion, in every aspect of a human's life. ${ }^{85}$ Depending on one's religiosity, Muslims would strive to do not just the wajib acts but also the mustahab ones, as the Qur'an describes in Surah Al Insan, 76:6-22.

\section{2) Permissibility of the Use of} Explosive-Type Weapons

IHL does not prohibit the use of explosive-type weapons per se. The rule that has to be observed, however, is that the choice of weapon and way of usage shall not be indiscriminate. ${ }^{86}$ However, while these explosive type weapons naturally have a blast radius, it is also a reality that modern warfare cannot really avoid using them. Therefore, to reconcile this, comes the principle of proportionality and the requirement of precautionary measures. ${ }^{87}$

In IsHL, however, there are differences of opinion among the jurists: the majority of contemporary jurists have allowed it, while some do not. ${ }^{88}$ Those who allow it base their opinions on the Qur'an in Surah At-Tawbah, 9:36 “..fight against the disbelievers collectively as they fight against you collectively.." (and everyone seems to be using explosives), and because Prophet Muhammad has used mangonels. ${ }^{89}$ This view is used by modern Muslim armies. ${ }^{90}$

81 Yunus Gilani and Tazul Islam, "Early Islam and Prisoners of War: A Study in Ethical Inferences", Hamdard Islamicus, Vol. 32, No. 3, July 2009, pp. 7-21, at p. 12-13. See also: Ray Murphy and Mohamed M. El-Zeidy, 'Prisoner of War: A Comparative Study of the Principles of International Humanitarian Law and the Islamic Law of War', International Criminal Law Review, Vol. 9, 2009, pp. 623-649, p. 641.

82 There are five legal injunctions in fiqh: Wajib: compulsory acts which will be rewarded and punished if violated, Mustahab: which will be rewarded if done but not punished if violated, Makruh: discouraged acts which will not incur punishment if committed, but will be rewarded if avoided, Haram: prohibited acts which deserve punishment, and rewards if avoided, and Mubah: lawful acts that are neither prohibited nor encouraged, See: Note 35, Dien, pp. 96-99.

83 E.g. The Qur'an in Surah Al-Baqarah, 2:83, Surah An-Nisa, 4:10, Al-Ma'un, 107:1-7, and numerous other Qur'anic verses and Sunnah mentioning the significance in charity.

${ }^{84}$ Ismail ibn Kathir, Op.cit., p. 289.

85 Mawil Izzi Dien, Op.cit., p.35.

86 Meaning, unable to distinguish combatants and non-combatants. See Articles 51(4), 51(5), 57, and 58 of AP I.

${ }^{87}$ See the previous discussion regarding the principle of proportionality.

88 See Fatwa of the Al-Khoirot Institute, "Hukum Penggunaan Bom dan Bahan Peledak dalam Perang", http://www.alkhoirot.net/2015/03/ hukum-bom-dalam-islam.html, accessed 16 April 2015.

89 the artillery type weapons of the time, so by virtue of qiyaas then artillery type weapons of today should be able to be used Note 63 , ibn Rushd, pp. $460-461$.

90 E.g. during very recent Saudi coalition airstrike against the Houthis in Yemen Al Jazeera, "Saudi and Arab Allies Bomb Houthi Positions in Yemen", http://www.aljazeera.com/news/middleeast/2015/03/saudi-ambassador-announces-military-operation-yemen-150325234138956. html, accessed 16 April 2015. 
The alternate view prohibiting the use of explosive-type weapons, however, is interesting. These jurists associate explosives with punishing with fire and mutilating, which are prohibited. ${ }^{91}$ See also the discussion on the IsHL perspective on the principle of proportionality, being integral to the arguments relevant to this opinion.

It is certainly understood that the alternate view may be not feasible given the trend of modern combat, and it is very tempting to decide based on maslahah. On may have to see the previously mentioned maxim of Islamic jurisprudence "the removal of harm takes precedence over achieving maslahah", in the light of another maxim in the same group: "a greater harm is eliminated by a lesser harm" 92 However, from the perspective of IHL, this opinion heavily inclines to a greater possibility to reduce incidental losses during attacks (despite being a minority opinion).

\section{c. Interaction III: Possible Conflicts between IsHL and IHL}

There are a number of issues where there may be possible conflicts between IsHL and IHL, which are perhaps would deserve most attention. These are among those pointed out by only some honest 'islamophobes', and usually easily dismissed by the apologists. Some identifiable issues are as follows:

\section{1) The Permissibility to Use Fire \\ IHL does not have any strict}

prohibition per se regarding the use of fire in warfare. The only restriction that international law applies is to make sure that non-combatants, civilians, and the surrounding environment do not get too much damage from the flames, i.e. Protocol on the Prohibitions or Restrictions on the Use of Incendiary Weapons (1980). ${ }^{93}$

However, burning a war captive alive is not only very likely to be a war crime of willful killing, ${ }^{94}$ but also considered to be an inhumane act in breach of Common Article 3 of the Geneva Conventions 1949. ${ }^{95}$ It is perhaps a common sense of humanity that the rationale behind that would be the slow and painful death caused by fire, which is terribly inhumane. One may then wonder, if the inhumaneness is indeed the slow and painful death, why is it then allowed during the course of warfare and not considered as unnecessary suffering and/or superfluous injury as per Article 35(2) of AP I.

From the perspective of IsHL, there is a difference of opinion among the jurists. Some of the opinions prohibit the use of fire, while others allow the use of fire only in retaliation. ${ }^{96}$ In this case, there is no disagreement with IHL. The problem arises in the case of punishment.

While there is a clear cut prohibition from Prophet Muhammad

91 The effects of explosive weapons can amount to exactly that, which distinguishes from mangonels. There are controversies in the matter of punishing with fire, which will be explained later. See: note 63, ibn Rushd, p. 461.

92 Imam Abu Dawud, Op.cit., p. 97.

93 See Article 1(5) and 2 of that Protocol. Note that this is not too different from what the principle of proportionality dictates, probably making notice on the special character of incendiaries (i.e. flames).

94 This is apart from the matter of legality of execution of war captives, which will be discussed later.

95 See the UN Statement regarding the burning of the Jordanian pilot, associating it with inhumane acts: United Nations Press Release, "On the Escalation of Incitement Rhetoric in Response to the Murder of Jordanian Pilot Moaz al-Kasasbeh", http://www.un.org/en/preventgenocide/ adviser/pdf/2015-02-06.Statement\%20on\%20the\%20escalation\%20of\%20incitement\%20rhetoric\%20in\%20response\%20to\%20the\%20 murder\%20of\%20Jordanian\%20pilot.pdf, accessed 16 April 2015.

96 Ismail ibn Rushd, Op.cit., p. 460. 
to use fire to execute a captive, ${ }^{97}$ the IS group issued a fatwa justifying the burning as mentioned earlier. There were three groups of justifications used by the IS group: ${ }^{98}$

a) Precedence by the Pious Predecessors in burning captives, i.e. by $\mathrm{Abu}$ Bakr, Khalid bin Walid, and that the prohibition of Prophet Muhammad to use fire was merely a statement of humility and modesty

b) The use of Qishaash (retaliation), since the Jordanian pilot previously joined a campaign to bombard civilians which allegedly burns them.

c) Some big jurists of Islamic jurisprudence from the Shaf'i and Hanafi school allowed such a punishment

As also has been mentioned earlier, the Fatwa Committee of Egypt basically argued that the precedence of Abu Bakr and Khalid bin Walid were not authentic, the command by Prophet Muhammad was a clear cut prohibition and not to be understood as mere humility, and that even a deserved death penalty shall observe the proper means (i.e. not using fire). ${ }^{99}$

However, the problem remains in the argument of qishaash. The general illegality of burning as punishment was easily concluded. ${ }^{100}$ And now we should consider the prescription of qishaash ${ }^{101}$ which means to commit an act to a person just as what the person has committed to others. ${ }^{102}$ Earlier, it has been mentioned by ibn Rushd how some jurists did allow the use of fire for qishaash, and it may be these jurists referred to by IS in their third point. So which provision abrogates which?

If the basis to prohibit burning abrogates the prescription of qishaash, as the Fatwa Committee of Egypt argued, then IsHL is consistent with IHL. If the prescription of qishaash abrogates the prohibition of burning, as the IS Fatwa Committee argued, then IsHL is inconsistent with IHL. An argument of reciprocity (or retaliation) is impermissible because compliance to IHL should not be subject to reciprocity. ${ }^{103}$ It is unfortunate that the Fatwa Committee of Egypt did not refute the qishaash claim of IS -merely submitting their own claim-and the matter is still open to juristly debate to determine the stronger opinion.

\section{2) The Execution of War Captives}

IHL only prohibits summary execution for mere captivity implying that captives may be executed upon trials -albeit with numerous requirements of fair trial. ${ }^{104}$ While almost all Islamic states have acceded to the Geneva Conventions 1949, thus

$97 \quad$ Ibid.

98 News Week, "ISIS Publish Pamphlet On How to Treat Female Slaves", http://www.newsweek.com/isis-release-questions-and-answerspamphlet-how-treat-female-slaves-290511, accessed on 16 April 2015.

99 Dar al-Ifta al-Missriyyah, "Egypt's Dar al-Iftaa Vehemently Condemns the Heinous Murder of the Jordanian Pilot by the Bloodthirsty QSIS", http://eng.dar-alifta.org/foreign/ViewArticle.aspx?ID=660\&CategoryID=1, accessed on 16 April 2015.

100 The general allowance to slay the enemies in war (without restriction of means) in the Qur'an at Surah At Tawbah, 9:5 but a specific prohibition if using fire as per the previous prohibition, thus an abrogation is easily made, Note 63, ibn Rushd, p. 460 .

101 Surah Al Baqarah, 2: 178-179.

102 Mustafa al-Bugha et al., 2007, Fikih Manhaji, Darul Uswah, Yogyakarta, p. 537.

103 Legal Consequences for States of the Continued Presence of South Africa in Namibia (South West Africa) notwithstanding Security Council Resolution 276 (1970), Advisory Opinion, I.C.J. Reports 1971, p. 16., para. 96.

104 Doswald-Beck and Haenckarts, Op.cit., pp. 354-370, See also how Common Article 3 of the Geneva Conventions 1949 only prohibits the murder and execution of captives without proper trials. 
recognizing the aforementioned rule, is it because or despite IsHL?

There is a difference of opinion on the matter. Some jurists say that it is within the discretion of the Muslim leader to see the maslahah of the Muslims, so if execution seems best then the said leader may instruct execution upon his discretion. ${ }^{105}$ Others mention that captives cannot be executed. ${ }^{106}$ The difference of opinion is because Surah Muhammad, 47:4 states that when an enemy is subdued then the options are either release by ransom or by kindness (not mentioning execution) and that there was an ijma (consensus) of The Companions on this matter, but there were also cases where Prophet Muhammad executed captives, hence the difference: which abrogates which? ${ }^{107}$ Ibn Rushd's conclusion is that the majority of jurists at the time say that execution of captives is the discretion of the Muslim leader, ${ }^{108}$ alike what ibn Nuhaas says. ${ }^{109}$ This view is against IHL.

However, modern jurists such as Yusuf al-Qardhawi points out that the precedence of captive executions by Prophet Muhammad were due to certain crimes committed by the captives beyond their participation of belligerency. ${ }^{110}$ Therefore, it can be concluded that the position of the Islamic states in acceding to the Geneva Conventions 1949 and agreeing that captives may not be executed for mere captivity actually has basis in IsHL. In this opinion, IsHL and IHL are compatible.

\section{3) The Act of Slavery}

The Slavery Convention of 1926 and Supplementary Convention on the Abolition of Slavery (1956) universally outlaws slavery, and in context of an armed conflict it is a violation of laws and customs of war, ${ }^{111}$ as mentioned by AP II. ${ }^{112}$ The Rome Statute only mentions slavery as a crime against humanity in Article 7(1)(c), while the provisions on war crimes only include sexual slavery. ${ }^{113}$

What does IsHL have to say about slavery? The majority of medieval jurists say that, it is the discretion of the Muslim leader to decide to enslave the captives on the basis of maslahah. ${ }^{114}$ While the Qur'an does not mention anything about the permissibility of taking slaves at the end of war, ${ }^{115}$ there is no secret that The Prophet has on some occasions enslaved captives. ${ }^{116}$

105 Ibn Nuhaas (d. 1411), "Mashari AlAshwaq Ila Masari Al-Ushaaq Wa Mutheer Al-Gharaam Ila Daar Assalaam, English translation: ibn Nuhaas, nd, The Book of Jihad (English translation by Noor Yamani)", http://api.ning.com/files/qnlif5STwXWJlDpiD8eR4ZJaME0iA eChqROisCh9REBFkr*W8yLdvIgQU-DjaJtNHTh1BG5Tmz20bVZDZmrci6TNPb5lEYS/MashariAlAshwaqilaMasarialUshaaqRevised Edition.pdf, accessed 16 April 2015, pp. 161-162.

106 Imam Shaybani (d.805). Kitab al-Siyar al-Saghir, English translation: Imam Shaybani, 1998, The Shorter Book on Muslim International Law (English Translation by Mahmood Ahmad Ghazi), Islamic Research Institute, Islamabad, para. 27.

107 Ismail ibn Rushd, Op.cit., pp. 456-457.

108 Ibid.

109 The Salafi Jihadist movements, including the Al-Qaeda, take their guidelines from the opinion of ibn Nuhaas, See: Chettan Bhatt, "The Virtues of Violence: The Salafi-Jihadi Political Universe", Theory Culture Society, Vol. 31, No. 1, 2014, pp. 25-48, at p.28

110 Yusuf Qardhawi, 2010, Fiqih Jihad, Mizan, Bandung, pp. 708-710.

111 Prosecutor v. Krnojelac., Trial Chamber Judgment, the International Criminal Tribunal for the former Yugoslavia (2002), para.10.

112 Article 4(2)(f).

113 But it may be argued that the act of slavery, which is seen to be against human dignity (See the Preamble to the Supplementary Convention on the Abolition of Slavery [1956]), could be a war crime of inhumane treatment.

114 Either to enslave, free by ransom, free without ransom, or execute. See note: Note 63, ibn Rushd, pp. 456-457 and Note 102, ibn Nuhaas, pp. 161-162.

115 See Surah Muhammad, 47:4.

116 See also references of how it is permissible for a man to have sexual intercourse with his female slave, see: Surah al-Mu'minun, 23:5-6. 
Before anything else, it is worth mentioning that the laws of treatment towards slaves in Islam are unlike what one sees practiced in most parts of the world -there is an unprecedented humaneness in it. ${ }^{117}$ This is not yet to mention numerous verses of the Qur'an encouraging the manumission of slaves. ${ }^{118}$ Therefore, modern jurists have an overwhelming majority opinion that Islam does not teach slavery, but provides a gradual mechanism to abolish it. ${ }^{119}$ This opinion is consistent with IHL.

However, it has been mentioned that there is dishonesty in covering up the issue of slavery. ${ }^{120}$ The position allowing slavery may seem safer from an Islamic law perspective, because there was no clear prohibition of slavery as the other opinion acknowledges as well. According to these groups of jurists, a gradual prohibition lacks evidence. ${ }^{121}$ This opinion, despite the extra humane treatments that Islam provides, ${ }^{122}$ still breaches IHL because the Islamic version slavery still has certain rights typically identified with ownership such as buying and selling slaves. ${ }^{123}$

\section{The Need for a Global Consensus}

\section{a. Function and Procedural Possibili- ties of an Ijma}

Prophet Muhammad has been reported to say "The difference of opinion among my people is a mercy". However, this saying is fabricated. ${ }^{124}$ The Qur'an has mentioned the virtues of unity and how bad disunity is. ${ }^{125} \mathrm{On}$ the other hand, Prophet Muhammad has been authentically reported to say "My people will never agree on an error" which became basis for jurists to say that ijma is a very important source of Islamic law. ${ }^{126}$ Future generation jurists of the Shafi'i school of thought mentions that it should be a consensus of the jurists of the entire community. ${ }^{127}$

The first modern ijma made was the Cairo Declaration, made by heads of the world Islamic states whom may represent their people but not necessarily the jurists.

117 The rules include: that slaves may only be taken through war, and a free man may not be enslave, may not be overburdened, and even if so then the master shall assist the slave, shall be fed and clothed with the same quality of what is eaten and worn by the master, slaves may not be abused, and if abused then they must be freed, may not be called with bad names such as 'my slave', rather they must be called 'my boy' or 'my girl', The child of a slave from the Master is not a slave, Slaves may not be forced into prostitution, and even most interestingly slaves have rights to request an agreement of manumission/freedom if they wish so, and it shall be made easy for them. For further discussion on slavery, see: Surah An-Nur, 24:33, Note 29, ibn Kathir, Vol. 7, pp. 78-79, Sayyid Saeed Akhtar Rizvi, "Slavery: from Islamic and Christian Perspectives", http://www.al-islam.org/slavery-from-islamic-and-christian-perspective-sayyid-akhtar-rizvi, accessed on 16 April 2015, especially at chapter "Islam Attacks Slavery", and also "Islam House", "Slavery in Islam", http://d1.islamhouse.com/data/en/ih_articles/ single2/en Slavery in islam.pdf, accessed on 16 April 2015.

118 For example Surah Al Balad, 90:12-14, Surah Al-Mujadilah, 58: 3, and so many more.

119 This is the position of the Fatwa Committee of Egypt: Dar al-Ifta al-Missriyyah, "Why Didn't Islam Abolish Slavery Immediately", http://eng. dar-alifta.org/foreign/ViewFatwa.aspx?ID=6830\&text=slavery, accessed 16 April 2015, see also the Open Letter to Baghdadi.

120 For example, that the Open Letter to Baghdadi ignored the fact that some scholars e.g. the Fatwa Committee of the Kingdom of Saudi Arabia's position is that slavery may be reintroduced at the discretion of the Muslim leader based on Maslahah.

121 A similar case of 'gradual prohibition' is intoxicants, which were not prohibited directly but rather step by step. However, at the end before Prophet Muhammad died the prohibition was made clear in the text - unlike that of slavery. Note 29, ibn Kathir, but with a different English version used: ibn Kathir, 2009, Tafsir ibn Kathir (English Translation by Muhammad Saed Abdul-Rahman), MSA Publication Ltd., London, pp. 140-141.

122 It is worth mentioning that the fatwa in Note 48 mentions that one of the virtues of slavery is to put the slaves in question under the care of the master.

123 Article 1(1) of the Slavery Convention (1926) defines the status of slavery as " [...] the status or condition of a person over whom any or all of the powers attaching to the right of ownership are exercised".

124 Fawa Team of Islamweb, "Fatwa No.7158, The Difference of Opinion among my Ummah is a Mercy", http://wwwislamweb.net/emainpage/ index.php?page =fatwa, accessed on 16 April 2015.

125 Surah al-Anfal, 8:46, Surah ar-Rum, 30: 31-32, Surah Hud, 11: 118-119

126 Note 74, Khadduri, at Introduction, p. 38. See also Note 35, Dien, pp. 46-47.

127 Ibid, Khadduri, pp. 38-39. This was the opinion of Imam al-Ghazzali. Compare this to the opinion of the founder of the Shafi'i school, Imam Shafi'i himself, saying that an ijma is only made when the actual entire community agrees, as long as such agreement is based on the Qur'an and Sunnah. See also Ibid, Khadduri, pp. 285-287. 
Next, it was the jurists that have united to refute IS through the Open Letter to Baghdadi, yet some parts of the content may have been dishonest and there is a lack of representation of jurists. ${ }^{128}$ Further, the Open Letter to Baghdadi ${ }^{129}$ was reactive to a particular issue, and the Cairo Declaration did not extend to laws of war.

Imam al-Ghazzali mentioned that the difficulty to arrive at a global ijma of the Muslims is mere procedural, meaning that there is a lack of method from which to achieve an ijma. ${ }^{130}$ However, the world today provides numerous international forums and the advancement of technology has made it easier. Therefore, formally, there should be no problems to achieve an ijma.

\section{b. Substantive Possibilities of an Ijma}

Will there be any problems on the substance? There will definitely be no problem at all with respect to the first level of interaction i.e. simple compatibilities between IsHL and IHL. When there is total conformity between most (if not all) schools of Islamic jurisprudence and IHL, then IsHL can be written simply as it is. But how about the possible incompatibilities?

The first possible incompatibility was regarding the use of fire as punishment. The difference of opinion is overwhelmingly against that of IS. Afterall, the Fatwa Committee of Egypt has already provided a counter qishaash argument as mentioned earlier, and all left to do is to explain the flaw of the IS argument and agree upon it.
The second and third incompatibility is regarding summary execution and enslavement towards war captives. While the one side of the different opinion inclines to be compatible to IHL, the other inclines to be incompatible to IHL. However, there are two levels of possibilities of reconciliation with regards to the matter of summary execution and enslavement. The first possible way would be to find the stronger opinion between the two different opinions, similar to that of the case of using fire as punishment.

The second possible way may seem to be a more pragmatic but very realistic way which may actually work. Even following the opinion that summary execution and enslavement can be done by the discretion of the Muslim leader depending on the Maslahah: why not have an ijma on a new maslaha of today?

In the past, the international situation was tolerant and encouraging in the case of slavery therefore it is not against the Maslahah to conduct it. ${ }^{131}$ Yusuf alQardhawy has explained that executions of captives at Prophet Muhammad's time was for Maslahah at the time, i.e. the interest of justice for special crimes. ${ }^{132}$

In the international system existing today which may demand state and individual responsibility for summary execution and slavery, Maslahah may be in favor of deciding against those acts. The reason why this possibility is the closest to success is because most Islamic states are already parties to the relevant international agreements, ${ }^{133}$ and

128 World Islamic Scholars, "Open Letter for Baghdadi”, http://www.lettertobaghdadi.com/, accessed on 16 April 2015.

129 Irrespective of some problems in its content, as discussed earlier.

130 Khaduri, Op.cit., p. 38.

131 See Surah Muhammad, 47:4

132 Also meaning that they were not summary executions, See Note 107, note also that during the medieval times, it may seem to be not an uncommon thing to execute prisoners, for example during the Crusades, Salahuddin al-Ayyubi executed the French captives in retaliation to King Richard executing Muslim captives (see Francois Guizot, 2008, A Popular History of France from the Earliest Times, Vol: II, BiblioLife, Charleston).

133 Thus exercising their discretion. Not only the Geneva Conventions 1949, but the vast majority of the Islamic states are parties to the Supplementary Convention on the Abolition of Slavery, as recorded by the UNTC, "Treaties", https://treaties.un.org/pages/ViewDetailsIII. aspx?src $=$ TREATY\&mtdsg no $=X V I I I-4 \&$ chapter $=18 \&$ Temp $=m t d s g 3 \&$ lang $=e n$, accessed on 16 April 2015. 
it conforms to the most extreme opinion as well.

\section{c. A Codified IsHL: A Source of International Law?}

After an ijma has been met and the IsHL has been codified into one document, what implications will it make? It will highly depend on what instrument will the codification formally be made into.

A first option would be a binding International Treaty. The positive feature is that they would directly become a primary source of international law for the Islamic states. However, it may be difficult if one were to also involve the jurists because it would not be easy to let them sign and ratify the treaty in question, and might only provide room for the heads of states. ${ }^{134}$ Further, international treaties would require a tedious lot of mechanisms regarding adoption to national legislations of the contracting parties and not to mention the wait until it enters into force. ${ }^{135}$

The second option may seem to have a brighter prospect, i.e. making the IsHL a soft law instead. The term soft law implies that the law is not formally binding. ${ }^{136}$ However, soft laws represent the opinio juris of the parties involved and, as the Nicaragua Case has shown, mere opinio juris can reflect customary international law even in the absence of state practice. ${ }^{137}$

This is not to mention that there is actually state practice already -somewhatestablished even before the IsHL Codification is to be made. If the Islamic states are already parties to the Geneva Conventions 1949 to begin with, ${ }^{138}$ while the IsHL Codification is compatible with IHL anyways, then all that is missing would be the opinio juris stating the corridor of Islamic law to accept the alreadyimplemented provisions. This is as opposed to international treaties that, for some countries, would require incorporation to national legislation with an already existing legislation on IHL from their previous ratification or accession.

But then, how does one put state leaders and Islamic jurists in one table for a conference? A lesson may be taken from the experience of the Codex Alimentarius (Codex) -albeit with a little twist. The Codex is a compilation of international food safety standards issued by the Codex Alimentarius Commission, a committee of experts established by the World Health Organization, which is not binding. ${ }^{139}$ However, the World Trade Organization then adopted the Codex as a reference in one of their binding agreements. ${ }^{140}$ In the light of that precedence, the OIC can facilitate a world conference of Islamic jurists to make their ijma in codifying the IsHL, and then hold their own session of members to endorse the product. Therefore, we now have (a) a codified IsHL, (b) a honest ijma of scholars, and (c) an ijma of the Muslim world represented by their leaders.

\section{Conclusion}

Why the fuss of an ijma, if the end conclusion is that IsHL and IHL could be made compatible anyways? There is a need to formally address the issue of IsHL honestly, to tackle both extreme views. The apologists need not to hide anything anymore,

See Article 7 of the VCLT 1969 regarding Full Powers of the representative of the states.

Ibid, see provisions on expressing consent to be bound as well as entry into force (Section 2-3).

6 Bryan A. Gardner (Ed.), 2009, Blacks Law Dictionary (9th ed.), West, St. Paul, p. 1519.

137 Militarv and Paramilitary Activities in and against Nicaragua (Nicaragua v. United States of America), Merits, Judgment. I.C.J. Reports 1986, p. 14, para 188 and 191-193.

138 Which they would have already implemented the provisions in their national legislation.

139 Gregory C. Shaffer and Mark A. Pollack. "Hard vs. Soft Law: Alternatives, Complements, and Antagonists in International Governance", Minnesota Law Review, Vol. 94, No. 3, 2010, pp. 706-799, pp. 756-757.

140 i.e. Article 3(4) of the Agreement of Sanitary and Phytosanitary Measures. 
and there is now a formal unified document to slam at the faces of the 'islamophobes'.

One may no longer claim that the acts of the Islamic states in acceding to IHL instruments are despite of Islamic laws. The ijma provides a corridor to bridge between the two laws: either by juristic discussions in choosing stronger opinions, or agreeing upon the maslahah of the Muslims today, and therefore legal under all different opinions in the contended matters.

The issue of radical groups, especially IS and the likes, is a tricky matter. Would they listen to the ijma? One would reasonably be pessimistic. However, with the ijma then the view will be more undeniably "Islamically legitimate", ${ }^{141}$ which will further isolate extremism.

\section{BIBLIOGRAPHY}

\section{A. Holy Scripture}

Allah, 1430 H, Al Qur'aanul Kareem, Majma Al Malik Fahd for Holy Qur'an Printing, Madinah.

\section{B. Books}

Abu Dawud, 2008, Sunan Abu Dawud (translated to English by Ahmad Hasan), Darussalam, Riyadh.

al-Bugha, Musthafa, et al., 2007, Fikih Manhaji, Darul Uswah, Yogyakarta.

al-Bugha, Musthafa, et al., 2006, Syarah Riyadus Shalihin, Darul Uswah, Yogyakarta.

von Denffer, Ahmad, 2014, Ulum al Quran: An Introduction to the Sciences of the Quran, The Islamic Foundation, Leicestershire.

ad-Dhahabi, Imam, Siyaar A'lam An Nubala', Dar al-Hadith, Cairo.

Doswald-Beck, Louis and Jean-Marie Haenckarts, 2005, ICRC Customary International Humanitarian Law, Vol. I: Rules, Cambridge University Press.

Gardner, Bryan A. (Ed.), 2009, Blacks Law Dictionary (9th ed.), West, St. Paul.

Ghazi bin Muhammad, et al., 2013, War and Peace in Islam: The Uses and Abuses of Jihad, The Royal Islamic Strategic Studies Centre and the Islamic Texts Society, Cambridge.

Guizot, Francois, 2008, A Popular History of France from the Earliest Times, Vol. II, BiblioLife, Charleston.
Hallaq, Wael B., 2009, An Introduction to Islamic Law, Cambridge University Press, New York. ibn Hisyam, 2006, Sirah Nabawiyah (trans. by Fadhli Bahri), Darul Falah, Bekasi.

ibn Kathir, 2000, Tafsir ibn Kathir (translated into English, Edited, and Abridged by SafiurRahman Al-Mubarakpuri), Darussalaam Publishing, Riyaadh.

Khadduri, Majid (Ed.), 1987, Al-Shafiis Risala: Treatise on the Foundations of Islamic Jurisprudence, The Islamic Texts Society, Cambridge.

Doswald-Beck, Louis and Jean-Marie Haenckarts, 2005, ICRC Customary International Humanitarian Law, Vol. II: Practices, Cambridge University Press, Cambridge.

Salahi, M. Adil, 1995, Muhammad: Man and Prophet, Elements Books, Dorset.

Malik, Imam, 1992, Al-Muwatta Malik (English Translation by Aisha Abdurrahman Bewley), Madinah Press, Granada.

Dien, Mawil Izzi, 2004, Islamic Law: From Historical Foundations to Contemporary Practice, University of Notre Dame Press, Notre Dame.

ibn Kathir, 2009, Tafsir ibn Kathir (English Translation by Muhammad Saed AbdulRahman), MSA Publication Ltd., London.

Muslim, Imam, 1972, Sahih Muslim (Trans. by Abdul Hamid Siddiqi), Ashraf Press, Lahore.

141 Rather than a gang of scholars arguing but with lack of representation, or a gang of heads of states, easily laughed at for being corrupt democratic kafirs -which is a view not inconceivable under the Qutb ideology, See Note 41. 
ibn Rushd, 2000, The Distingished Jurist's Primer

(Trans. by Imran Ahsan Khan Nyazee), Garnet Publishing, Reading.

Qardhawi, Yusuf, 2010, Fiqih Jihad, Mizan, Bandung.

Qutb, Sayyid, 2006, Milestones, Islamic Book Service Publisher, New Delhi.

Salih al-Fawzan bin Fawzan, nn, Kitab Durus Fi Syarhi Nawaqidhil Islam, Maktabah ArRushd, Saudi Arabia.

Shaw, Malcom, 2008, International Law (Sixth Edition), Cambridge University Press, New York.

Shaybani, Imam, 1998, The Shorter Book on Muslim International Law (Trans. by Mahmood Ahmad Ghazi), Islamic Research Institute, Islamabad.

\section{Journal Articles}

Ahmad, Abu Umar Faruq, et al., "Shari'ah Maxims and Their Implication on Modern Financial Transactions", Journal of Islamic Economics, Banking and Finance, Vol. 6, No. 3, JulySeptember 2010.

Bhatt, Chettan, "The Virtues of Violence: The Salafi-Jihadi Political Universe", Theory Culture Society, Vol. 31, No. 1, 2014.

Cockayne, James, "Islam and International Law: from a Clash to a Conversation between Civilizations", International Review of the Red Cross, Vol. 84, No. 847, September 2002.

Gilani, Yunus and Tazul Islam, "Early Islam and Prisoners of War: A Study in Ethical Inferences", Hamdard Islamicus, Vol. 32, No. 3, 2009.

Michael, George, "The Legend and Legacy of Abu Musab al-Zarqawi", Defence Studies, Vol. 7, No. 3, September 2007.

Muhammadin, Fajri Matahati, "The GPH-M.I.L.F. Agreement: Human Rights Provisions and Possible Overlaps", Jurnal Cita Hukum, Vol. I, No. 1, July 2014.

Murphy, Ray and Mohamed M. El-Zeidy, "Prisoner of War: AComparative Study of the Principles of International Humanitarian Law and the Islamic Law of War", International Criminal Law Review, Vol. 9, 2009.

Rane, Halim and Jacqui Ewart, "The Framing of Islam and Muslims in the Tenth Anniversary Coverage of 9/11: Implications for Reconciliation and Moving On", Journal of Muslim Minority Affairs, Vol. 32, No. 3, September 2012.

Shaffer, Gregory C. and Mark A. Pollack, "Hard vs. Soft Law: Alternatives, Complements, and Antagonists in International Governance", Minnesota Law Review, Vol. 94, No. 3, 2010. Wartel, Eva, "Humanitarians and Their Moral Stance in War: the Underling Values", International Review of the Red Cross, Vol. 876, December 2009.

\section{Internet Articles and Statements, and} Official Websites

Al Jazeera, "Saudi and Arab Allies Bomb Houthi Positions in Yemen", http://www.aljazeera. com/news/middleeast/2015/03/saudiambassador-announces-military-operationyemen-150325234138956.html, accessed on 16 April 2015.

Al-Akiti, Muhammad Afifi, "Defending the Transgressed by Censuring the Reckless Against the Killing of Civilians", http://www. warda.info/fatwa.pdf, accessed on 16 April 2015.

al-Bani, Muhammad Nasir ud-Deen, "Warning Against the Fitnah of Takfeer", http://abdurrahman.org/faith/ warningTakfirAlbani.html, accessed on 16 April 2015.

Al-Khoirot Institute, "Hukum Penggunaan Bom dan Bahan Peledak dalam Perang", http:// www.alkhoirot.net/2015/03/hukum-bomdalam-islam.html, accessed on 16 April 2015

Al-Tartousi, Abu Baseer, "A Declaration Regarding the Fighting Between the ISIS and the Mujahideen of Al-Sham", http:// www.abubaseer.bizland.com/hadath/Read/ 
hadath\%20101.pdf, accessed on 16 April 2015.

BBC, "Yemen Crisis: Who is Fighting Who?", http://www.bbc.com/news/world-middleeast-29319423, accessed on 16 April 2015.

bin Abdul Aziz, Abdul Qodir, "Panduan Fikih Jihad Fii Sabilillah, Maktab Nidaa ul-Jihad", http:// kopet.pun.bz/files/syaikh-abdul-qodir-abdul. $p d f$, accessed on 16 April 2015.

Dar al-Ifta al-Missriyyah, "Egypt's Dar al-Iftaa Vehemently Condemns the Heinous Murder of the Jordanian Pilot by Bloodthirsty QSIS", http://eng.dar-alifta.org/foreign/ViewArticle. aspx? $I D=660 \&$ Category $I D=1$, accessed on 16 April 2015.

Dar al-Ifta al-Missriyyah, "Why Didn't Islam Abolish Slavery Immediately", http:// eng.dar-alifta.org/foreign/ViewFatwa. aspx?ID $=6830 \&$ text $=$ slavery, accessed on 16 April 2015.

El Watan News, "Da'esh Issues Fatwa to burn Al Kasasbeh", http://www.elwatannews.com/ news/details/654891, accessed 16 April 2015.

Fatwa Committee of the Kingdom of Saudi Arabia, "Fatwa No. 1977, Part No. 16 Page 569572, English version of Fatwa al-Lajnah ad-Da'imah", http://www.alifta.com/default. aspx? languagename $=e n \# 1$, accessed on 16 April 2015.

Fawa Team of Islamweb, "Fatwa No.7158, Difference of Opinion among my Ummah is a Mercy", http://www.islamweb.net/ emainpage/index.php?page $=$ fatwa, accessed on 16 April 2015.

Hasan, Mehdi, "How Islamic is Islamic State?", http://www.newstatesman.com/worldaffairs/2015/03/mehdi-hasan-how-islamicislamic-state, accessed on 16 April 2015.

Huffington Post, "Conversion to Islam One Result of Post-9/11 Curiosity", http://www. huffingtonpost.com/2011/08/24/post-911islam-converts_n_935572.html, accessed on 16 April 2015. ibn Nuhaas, nd, "The Book of Jihad (Trans. by Noor Yamani)", http://api.ning.com/ files/qnlif5STwXWJllDpiD8eR4ZJaMEO i A C ChqRO is Ch9REBFkr*W8yLdvIgQU-DjaJtNHTh $1 B G-$ 5 Tmz 20 bVZDmrci6TNPb5lEYS/ MashariAlAshwaqilaMasarialUshaaqRevisedEdition.pdf, accessed on 16 April 2015.

ICRC Official Website, “1949 Conventions and Additional Protocols, and their Commentaries", https://www.icrc.org/applic/ ihl/ihl.nsf/vwTreaties 1949.xsp, accessed on 16 April 2015.

Islamophobia Watch, "Another Fake AntiIslam Quote from the Far Right", http:// www. 'islamophobia'watch.co.uk/anotherfake-anti-islam-quote-from-the-far-right/, accessed on 16 April 2015.

McClatchy DC, "Al-Qaida's ISIS Takes 2 Syrian Cities, Executes Scores of Rivals", http:// www.mcclatchydc.com/2014/01/13/214335/ al-qaidas-isis-takes-2-syrian.html, accessed on 16 April 2015.

New York Post, "ISIS Burns Pilot Alive, Jordan Responds with Terrorist Executions", http:// nypost.com/2015/02/03/isis-video-appearsto-show-jordanian-pilot-being-burnedalive/, accessed on 16 April 2015.

New York Times, "Multiple Fronts in the Fight Against ISIS", http://www.nytimes.com/ interactive/2014/06/12/world/middleeast/ the-iraq-isis-conflict-in-maps-photos-andvideo.html?_r=0, accessed on 16 April 2015.

News Week, "ISIS Publish Pamphlet On How to Treat Female Slaves", http://www.newsweek. com/isis-release-questions-and-answerspamphlet-how-treat-female-slaves-290511, accessed on 16 April 2015.

Islam House, "Slavery in Islam", http:// d1.islamhouse.com/data/en/ih_articles/ single2/en_Slavery_in_islam.pdf, accessed on 16 April 2015. 
Rizvi, Sayyid Saeed Akhtar Rizvi, "Slavery: from Islamic and Christian Perspectives", http:// www.al-islam.org/slavery-from-islamic-andchristian-perspective-sayyid-akhtar-rizvi, accessed on 16 April 2015.

Tahir-ul-Qadri, Muhammad, "Fatwa on Terrorism and Suicide Bombing", http://www. quranandwar.com/FATWA\%20on\%20 Terrorism\%20and\%20 Suicide\% 20 Bombings.pdf, accessed on 16 April 2015.

The Independent, "Syria Conflict: Idlib City Falls to Jabhat al-Nusra as President Assads forces Flee, Jihadists Claim", http://www. independent.co.uk/news/world/middle-east/ syria-conflict-idlib-city-falls-to-jabhatalnusra-as-president-assads-forces-fleejihadists-claim-10141020.html, accessed on 16 April 2015.

UN Treaty Collection (UNTC), for CEDAW, "Convention on the Elimination of All Forms of Discrimination against Women", https://treaties.un.org/Pages/ViewDetails. aspx?src $=$ TREATY\&mtdsg_no=IV$8 \&$ chapter $=4 \&$ lang $=e n$, accessed on 16 April 2015.

United Nations Press Release, "On the Escalation of Incitement Rhetoric in Response to the Murder of Jordanian Pilot Moaz al-Kasasbeh", http:// www.un.org/en/preventgenocide/adviser/
pdf/2015-02-06.Statement\%20on\%20 the $\% 20$ escalation\%20of\%20incitement $\% 20$ rhetoric\%20in\%20response\%20to\%20 the $\% 20$ murder\%20of\%20Jordanian\%20 pilot.pdf, accessed on 16 April 2015.

World Islamic Scholars, "Open Letter for Baghdadi”, http://www.lettertobaghdadi.com/, accessed on 16 April 2015.

\section{E. Case Laws}

Asylum Case (Columbia v. Peru), Merits Judgment, ICJ Reports 1950.

Eritrea v. Yemen Arbitration, PCA, Award of 1996.

Legal Consequences for States of the Continued Presence of South Africa in Namibia (South West Africa) notwithstanding Security Council Resolution 276 (1970), Advisory Opinion, I.C.J. Reports 1971.

Militarv and Paramilitary Activities in and against Nicaragua (Nicaragua v. United States of America). Merits,Judgment. I.C.J. Reports 1986.

Prosecutor v. Krnojelac., Trial Chamber Judgment, the International Criminal Tribunal for the former Yugoslavia, 2002.

Prosecutor v. Kupreskic et al., Trial Chamber Judgment, the International Criminal Tribunal for the former Yugoslavia, 2000. 